Research Paper

CidVANCE RESEARCH JOURNAL OF I M P R O V E M E N T Volume 5 | Issue 2 | Dec., 2014 | 101-104

$\bullet \bullet . . . \quad$ e ISSN-2231-640X

DOI :

10.15740/HAS/ARJCI/5.2/101-104

Visit us: www.researchjournal.co.in

\section{Yield, quality and soil fertility of cluster bean (Cyamopsis tetragonoloba L.) as influenced by various row spacing and levels of phosphorus}

\author{
S.K. YADAV ${ }^{1}$, A.G. PATEL ${ }^{2}$ AND B.L. YADAV
}

\section{Authors' Info} Associated Co-author : ${ }^{1}$ Department of Horticulture, C.P. College of Agriculture, S.D. Agricultural University, SARDARKRUSHINAGAR (GUJARAT) INDIA

${ }^{2}$ Fruit Research Station (S.D.A.U.), Dehgam, GANDHINAGAR (GUJARAT) INDIA

Author for correspondence: B.L. YADAV

Department of Agronomy, C.P.

College of Agriculture, S.D.

Agricultural University,

SARDARKRUSHINAGAR

(GUJARAT) INDIA

\begin{abstract}
A field experiment was conducted at Sardarkrushinagar Dantiwada Agricultural University, Sardarkrushinagar during Kharif season of 2010 on loamy sand soil. The treatments comprised of three levels of row spacing $\left(\mathrm{S}_{1}=30 \mathrm{~cm} \times 15 \mathrm{~cm}, \mathrm{~S}_{2}=45 \mathrm{~cm} \times 15 \mathrm{~cm}\right.$ and $\left.\mathrm{S}_{3}=60 \mathrm{~cm} \times 15 \mathrm{~cm}\right)$ and four levels

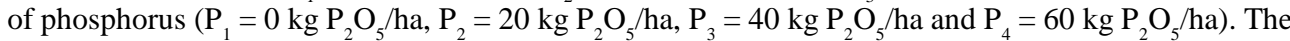
results under the study showed that the row spacing significantly influenced and wider spacing $(60 \mathrm{~cm} \times$ $15 \mathrm{~cm}$ ) produced maximum available nitrogen and available phosphorus in the soil after harvest whereas, maximum green pod yield and dry fodder yield was recorded in narrowest row spacing $(30 \mathrm{~cm} \times 15 \mathrm{~cm})$. The application of phosphorus significantly influenced the various yield and quality parameters and higher dose of phosphorus $\left(60 \mathrm{~kg} \mathrm{P}_{2} \mathrm{O}_{5} / \mathrm{ha}\right)$ was found superior in yield and quality characters under study. The $60 \mathrm{~kg} \mathrm{P}_{2} \mathrm{O}_{5} /$ ha recorded maximum pod yield and dry fodder yield.
\end{abstract}

Key Words : Spacing, Phosphorus, Soil fertility, Cluster bean

How to cite this paper : Yadav, S.K., Patel, A.G. and Yadav, B.L. (2014). Yield, quality and soil fertility of cluster bean (Cyamopsis tetragonoloba L.) as influenced by various row spacing and levels of phosphorus. Adv. Res. J. Crop Improv., 5 (2) : 101-104.

Paper History : Received : 28.05.2014; Revised : 19.10.2014; Accepted : 04.11 .2014 